\title{
Computer End-User Training, Learning and Evaluation in the New South Africa: A Port Elizabeth Technikon Experience
}

\author{
Annerie Retief \\ Department End-User Computing : Faculty of Computer \\ Studies, Port Elizabeth Technikon, Private Bag X6011, Port \\ Elizabeth, 6000, South Africa, tel: \& fax : +27 41 5043434, \\ email : annerie@ml.petech.ac.za
}

\begin{abstract}
End-user computing class groups consist of a wide spectrum of students which have deemed traditional lecturing and evaluation methods ineffective. We have developed computer-based tutorials and tests that motivate the students to explore and employ various features of the software products by using built-in coaches or help features. They become self-competitive and self-confident and re-evaluate themselves until they have reached the required standard to do the official evaluation.
\end{abstract}

\section{Keywords}

computer-based training, learning and evaluation, end-user computing, information technology

\section{INTRODUCTION}

'This is the year of the computer. So was last year. And so it will be next year. Indeed, every year seems to be the year of the computer. A never-ending string of innovative applications of computer and information technology continues to affect virtually everything we do.' (Long, 1993)

In 1982 the editors of Time chose the computer as Time's 'Man of the Year' because they felt it would change the way people live. Today we know that they were right. Many of us can agree with J.K. Galbraith and say 'we are becoming the servants in thought, as in action, of the machines we have created to serve us. Lo! Men have become the tools of their tools' (Long, 1994). 


\section{INFORMATION TECHNOLOGY AND SOCIETY}

\subsection{Various information technology application areas}

Geologists use geographical information systems to pinpoint rich mineral resources. Architects and other designers sell their traditional drawing equipment for a better replacement, namely computers for computer-aided design and manufacturing. Physicians use expert diagnosing systems to identify diseases, locate problems and prescribe treatment. Aeroplane and navy pilots rely heavily on global positioning information systems to guide them accurately.

At night Joe Soap leaves the electronical workhorse in the office to relax in a funpacked evening at home with an electronical 'play horse'or as Bornman (1995) calls it a 'jet-fighter-cool-sound-family-fun machine of multimedia' . Joe surfs the internet, visits some exciting sites and sends a message to a friend in Latvia. His daughter asks him to edit her multimedia school project. Joe is amazed at the new insights he gained from this project and is astonished by the wonderful world of multimedia encyclopaedias and his teenager daughter's creativity with technology. He realises that he is not only in the middle of an information revolution, but also in the midst of an exciting technological revolution. Information Technology indeed has an impact on all walks of life.

\subsection{Reconstruction and development and Information Technology (IT)}

In South Africa it is of vital importance to address issues concerning the government's Reconstruction and Development Program (RDP). According to Lahoud (1994), the RDP should be viewed as developing people who have not had the opportunities in the past, where information technology (IT) is a facilitator and a business opportunity. 'IT can boost education and could play a crucial role in the RDP campaign which offers tremendous untapped business opportunities' (Schwarz, 1994). The national RDP compels everyone in education and training to accept the challenge of creating a system which cultivates and liberates the talents of all our people without exception. In the light of the RDP, education and training must empower the individual, and improve quality of life.

We, at the Port Elizabeth Technikon, have realised that we cannot afford to ignore technology and its impact on our rapidly developing and changing new South African society and hope to help effectively and successfully in the RDP. More than $80 \%$ of the active workforce in South Africa is computer illiterate. IT has a huge role to play in education, both in mainstream education and retraining people. The re-education process and education of new people offers perhaps the greatest challenge to IT (Schwarz, 1994).

\subsection{The competitive advantage}

By their very nature, computers bring change. With the total amount of computing capacity in the world doubling every two years, we can expect even more dramatic change in the future. The cumulative effects of these changes are altering the basic constructs of society and the way we live, work and play (Long, 1994). 
It is our challenge to harness the power of the computer and direct it toward the benefit of society. To be an active participant in this age of information, we as a society and as individuals must continue to learn about and understand computers and be computer-competent.

Companies use IT to gain the competitive advantage. It is no longer possible for a company to achieve success and profits through good management and hard work, because these organisational qualities have become prerequisites for survival. 'In this highly competitive era, the judicious use of IT can make the difference between profitability and failure in just about every type of organisation' (Long, 1993).

\subsection{The end-user force}

End-user computing is a phenomenon in which end-users such as employees, managers and executives are directly involved with the development and use of IT. Through enduser computing, people are using the power of computer-based information systems directly to their own benefit. The dynamics of a rapidly advancing computer technology demand constant updating of skills and expertise. End-users are determined to get the information they want in a form and fashion they can use (Stair, 1992). It is crucial to train the end-user force effectively to be competent and independent to aid a company in gaining the competitive advantage.

\subsection{Training and learning necessary}

The eventual success of any system or application depends on how it is used and therefore how the users were trained in using the system. Austin (1995) holds the opinion that if a computer system is not living up to its promises, chances are that documentation and end-user training are to blame.

During training, the end-user should be acquainted with the application's capabilities, potential applications, on-line help aids and the user's fears and apprehensions should be eliminated (Gery, 1988; Stair, 1992). Due to the competitiveness of industry and changing technology, workers must be multiskilled, flexible and better trained, especially in the use of technology (Buckham, 1995).

'No one can remain current without continuous learning. Today education must be viewed as an integral part of our entire life span - not something we do and then we are finished with it' (Gaede, 1994).

\subsection{Experiential learning}

Here are some experts' opinions about learning:

'Learning is an active process whereby experience is converted into knowledge and skills' (Merrill, 1991).

'Instead of regarding knowledge as something that exists outside students which they must passively ingest, knowledge must be recognised as being socially and individually constructed on the basis of experience' (Reeves, 1994). 
'Knowledge without practice rarely, if ever, translates into skill or specific behaviour. The job situation is dynamic. Change is frequent; ongoing adaptation and learning is required' (Gery 1991).

\subsection{Computer-based training and learning}

We need to provide flexible learning experiences and create motivation to learn. Computer-based training (CBT) can be employed to create these learning experiences. $\mathrm{CBT}$ can be defined as 'an interactive learning experience between a learner and a computer in which the computer provides the majority of the stimulus, the learner must respond and the computer analyses the response and provides feedback to the learner'.

\section{END-USER TRAINING AT THE PORT ELIZABETH TECHNIKON}

In the exciting, multi-racial, multi-cultural, multi-faceted new South Africa today, it is of utmost importance to address the socio-political and socio-economical issues with regard to the government's Reconstruction and Development program.

The Port Elizabeth Technikon is known as a tertiary institution of academic excellence throughout Southern Africa, recognised by industry. Our students come from all walks of life throughout South Africa and even Namibia, Botswana, Zambia, Malawi and abroad.

The Department End-User Computing resorts under the Faculty of Computer Studies and acts as a service department for the entire Technikon and offer computer courses to students from various disciplines. We have an authorised Autodesk training centre and a Drake Prometric testing centre.

\subsection{Multi-faceted student body}

Class groups consist of a wide spectrum of students with differentiating factors among others : multi-racial, multi-cultural, multi-lingual. Many of our students come from an educationally disadvantaged background where they have been deprived of high quality education. Other students have alternative learning styles, varying learning needs, diverse learner entry knowledge or skill levels and differing job or career orientation needs, different priorities, distinct time frames and contrary interests.

\subsection{Computer training}

Apart from full time and part time formal courses, computer short courses are offered to industry, unemployed people and people who do not have credits to be enrolled for other formal courses at tertiary institutions. These courses vary from computer literacy, word processing, spreadsheets, data bases to query languages, basic operating systems, network administration to programming languages and computer-aided design and including any computer course requested by industry. 


\subsection{Computer short courses}

We realise that our training paradigm's operating assumptions and applications must not only overlap with reality, but must be congruent. If we do not keep in step with industry we as a Technikon will soon be out of business. We strive to address the problem of the large numbers of unskilled members of the broader community and industry to train them to be confident and be competent members of the workforce. Many students enrol for these computer short courses to enhance their careers.

\subsection{Teaching by doing}

The complexity of our student groups and various other factors, such as the lack of availability of public transportation after formal lecture hours, have deemed traditional lecturing and evaluation methods ineffective.

Apart from covering the theoretical component, the students are prepared for the practical component of a week, by discussions and computer-based illustrations in a classroom situation. Application packages are demonstrated. A top-down demonstration illustrates what the end result will be. The opposite bottom-up approach illustrates how to build the application towards the end-result. Both approaches are necessary to establish and maintain a balanced perspective of the application package. Pitfalls, traps, tips and techniques to solve problems are discussed and illustrated.

\subsection{Learning by using computer-based tutorials}

In the flexible Windows environment, we now have the ability to integrate computerbased exercises with applications software to permit concurrent execution of tutorials and interactive help. Until recently we could only dream of such a luxury!

Introductory step-by-step exercises are used in well equipped computer laboratories, to familiarise a student with a software package. Some of these exercises are computerbased and others paper-based. As the students progress, they work on more complex assignments which motivate them to explore and employ various features of the product by using the built-in coaches or HELP features of the packages. The exercises are designed primarily as revision tools and it is assumed that the students would have been previously exposed to the material by their lecturers' illustrations in class. The computer-based tutorials allow students to re-evaluate themselves until they have reached or exceeded the required standard to do the official evaluation.

We have seen that 'the more the learner can control the rate, sequence, repetition, approach to learning, practice exercises or problems and access to hints and HELP to accommodate personal learning style and needs, the more likely the learner is to like the experience and integrate the material' (Gery, 1988).

\subsection{Computer-based evaluation}

Evaluation of the theoretical component of our courses is completely computer-based by utilising Question Mark Professional 3.1. For practical evaluation the method applied depends on the student group and lecturer. In a Question Mark-based test, the student receives the questions in Question Mark, toggle to the application, work out an answer or solution and toggle back to Question Mark to answer the question. This 
evaluation method entails exactly the same process as the computer-based training tutorials.

Various other ways of evaluation in end-user applications are employed. Some Question papers pose a problem and contain instructions on what is expected. Other question papers pose a problem and illustrate the expected end result. In both instances the student has to create a new, or change an existing solution to the stated problem. The results of these computer-based tests are immediately available.

In 1994 all the practical tests were Question Mark-based. The students were apprehensive at first, but once they became familiar with this method of evaluation, they did not want to be evaluated in a traditional manner. They were familiar and comfortable with this consistent, reliable training, learning and evaluation method. We have found that all the so called 'advantages' of CBT were confirmed by the attitudes and feedback of most students. (In 1995 all the practical tests were manually marked to the utter frustration of lecturers and students.)

\subsection{Social impact}

'It costs five or ten times more to support an untrained user than a trained user'. (Hill, 1995)

The students completing our courses are able to use their acquired, enriched and enhanced experiential knowledge to become effective computer end-users or can use this knowledge as stepping-stones to a computer-related career. Their newly found computer competency enables them to be active and effective participants in the emerging information society. They can help and train themselves. They are trained to cope in an ever-changing environment to be able to meet and even exceed the performance requirements of a job and to be able to adapt effectively to continuous change. Our students stand tall and can face life with the knowledge of self-realisation by being employed; promoted or receiving better job offers.

Due to the popularity of our first year level formal course at the Technikon, we were approached to offer this course as an optional subject to a specific group of students. Although the students had to pay for an additional subject, the demand was overwhelming - all interested students could not be accommodated.

The students have expressed their gratitude on many occasions and in many ways and following are a few student comments :

- 'This cource has really given me insite of computers I thought that only geniuses could work on and understand computers and that I would never be able to understand. But now I do'

- 'now I know how to type and how to use a computer'

- 'The lecture must be compulsory for third years students' 


\section{REFERENCES}

Austin, T. (in Viedge, E., 1995) Footing the support bill. Information Technology, 2(7), 18-23.

Bornman, J. (1995) Showbiz PCs get to work. Information Technology, 2 (7), 40-4I

Buckham, B (1995) Shaping the learning curve. Information Technology, 2(11)

Gaede, O.F. (1994) Emerging and converging technologies: implications for education and training. In P.M. Alexander (Ed.) Computer-assisted education and training in developing countries.

Gery, G.J. (1988) Making CBT happen. Boston: Weingarten Publications.

Gery, G.J. (1991) Electronic performance support systems. Boston: Weingarten Publications.

Hill, M. (in Viedge, E., 1995) Footing the support bill. Information Technology, 2(7), 18-23.

Lahoud, B. (in Schwarz, H., 1994) Will the RDP be the miracle South Africa's economy need? Information Technology, 1(8), 8-11.

Long, L. and Long, N. (1993) Computers. New Jersey: Prentice Hall.

Long, L. (1994) Introduction to computers and information systems. New Jersey: Prentice Hall.

Merrill, D (1991) Constructivism and instructional design. Educational Technology.

Reeves, T.C. (1994) A model of the effective dimensions of interactive learning. In . P.M. Alexander (Ed.) Computer-assisted education and training in developing countries.

Schwarz, H. (1994) Will the RDP be the miracle South Africa's economy need? Information Technology, 1(8), 8-11

Stair, R.M. (1992) Principles of information systems: a managerial approach. Boston: Boyd \& Fraser Publishing Company.

\section{BIOGRAPHY}

Annerie Retief is a Senior Lecturer in the Department End-User Computing in the Faculty of Computer Studies at the Port Elizabeth Technikon at the southeastern tip of South Africa. She holds a Masters Diploma of Technology : Information Technology. Areas of research interest are expert systems, geographical information systems, intelligent computer-assisted learning. She believes that "on the planes of hesitation bleach the bones of countless millions who, at the dawn of victory, sat down to wait... and waiting, died" (George Cecil) and that "scarecrows are just dinner-bells of ripe opportunities" (anon). 